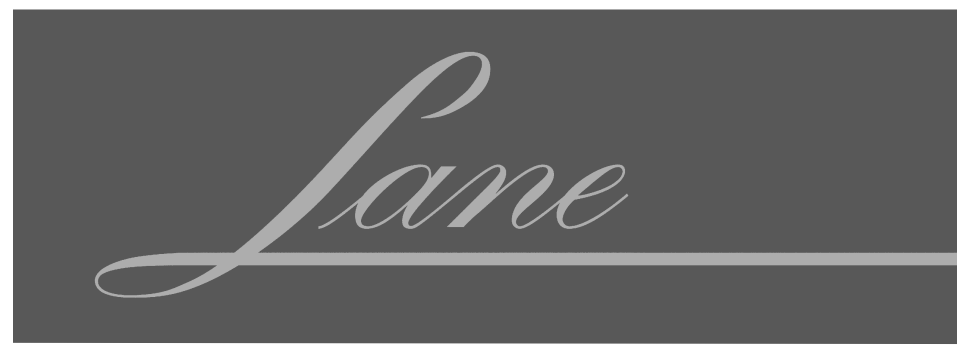

\title{
PALEONTOLOGY
}

\section{SPECIMEN CABINETS}

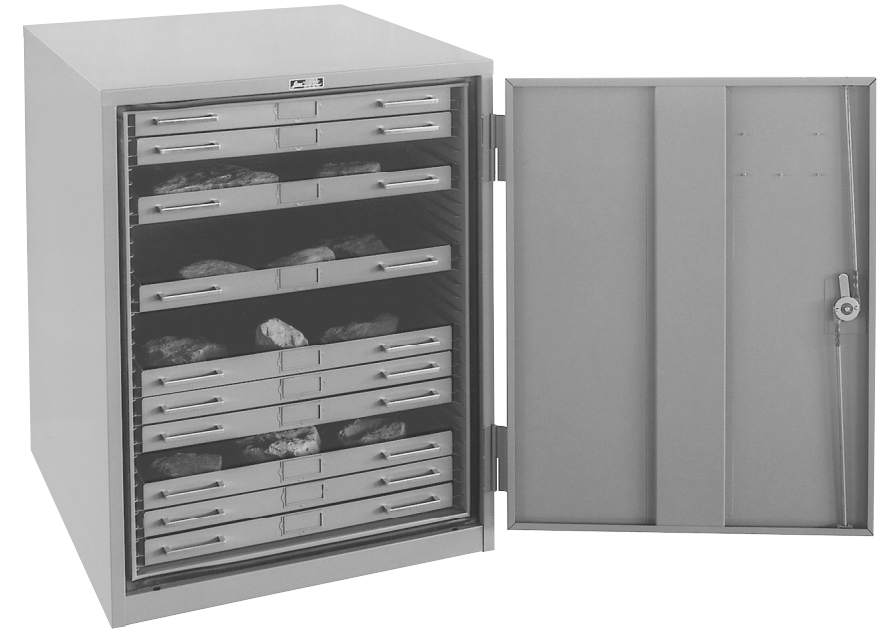

* All steel construction

* Powder paint finish

Durable door seal

No adhesives

Reinforced for easy stacking

Sturdy steel trays

\section{LANE SCIENGE EQUIPMENT GORP.}

225 West 34 th Street

Suite 1412

New York, NY 10122-1496
Tel: 212-563-0663

Fax: 212-465-9440

www. Ianescience.com 


\section{UNITED STATES \\ Statement of Ownership, Management, and Circulation $\overline{\text { POSTAL SERVICE }}_{\circledast}$ (All Periodicals Publications Except Requester Publications)}

1. Publication Title

\begin{tabular}{|l|}
\hline 2. Publication Number \\
$281-800$ \\
\hline 5. Number of Issues Published Annually
\end{tabular}

4. Issue Frequency

Jan, Mar, May, Jul, Sept, Nov
3. Filing Date

$10 / 01 / 2017$

6. Annual Subscription Price

6

7. Complete Mailing Address of Known Office of Publication (Not printer) (Street, city, county, state, and ZIP+4()

Cambridge University Press

1 Liberty Plaza

New York, NY 10006

8. Complete Mailing Address of Headquarters or General Business Office of Publisher (Not printer)

Cambridge University Press

Edinburgh Building, Shaftesbury Rd, Cambridge CB2 2RU, England

9. Full Names and Complete Mailing Addresses of Publisher, Editor, and Managing Editor (Do not leave blank)

Publisher (Name and complete mailing address)

Cambridge University Press

1 Liberty Plaza

New York, NY 10006

Editor (Name and complete mailing address)

Brenda R. Hunda, Cincinnati Museum Center

Jisuo Jin, Univ of Western Ontario

Hans-Dieter Sues, Smithsonian Institution

Managing Editor (Name and complete mailing address)

10. Owner (Do not leave blank. If the publication is owned by a corporation, give the name and address of the corporation immediately followed by the names and addresses of all stockholders owning or holding 1 percent or more of the total amount of stock. If not owned by a corporation, give the names and addresses of the individual owners. If owned by a partnership or other unincorporated firm, give its name and address as well as those of each individual owner. If the publication is published by a nonprofit organization, give its name and address.)

\begin{tabular}{l|l}
\hline Full Name & Complete Mailing Address \\
\hline The Paleontological Society & P.O. Box 9044 \\
\hline & Boulder, CO 80301 \\
\hline & \\
\hline
\end{tabular}

11. Known Bondholders, Mortgagees, and Other Security Holders Owning or Holding 1 Percent or More of Total Amount of Bonds, Mortgages, or Other Securities. If none, check box

$\rightarrow \square$ None

\begin{tabular}{l|l}
\hline Full Name & Complete Mailing Address \\
\hline & \\
\hline & \\
\hline
\end{tabular}

12. Tax Status (For completion by nonprofit organizations authorized to mail at nonprofit rates) (Check one)

The purpose, function, and nonprofit status of this organization and the exempt status for federal income tax purposes:

$\nabla$ Has Not Changed During Preceding 12 Months

$\square$ Has Changed During Preceding 12 Months (Publisher must submit explanation of change with this statement) 
JULY 2017

a. Total Number of Copies (Net press run)

\begin{tabular}{|c|c|c|c|c|}
\hline \multirow{4}{*}{$\begin{array}{l}\text { b. Paid } \\
\text { Circulation } \\
\text { (By Mail } \\
\text { and } \\
\text { Outside } \\
\text { the Mail) }\end{array}$} & (1) & $\begin{array}{l}\text { Mailed Outside-County Paid Subscriptions Stated on PS Form } 3541 \text { (Include paid } \\
\text { distribution above nominal rate, advertiser's proof copies, and exchange copies) }\end{array}$ & 266 & 274 \\
\hline & (2) & $\begin{array}{l}\text { Mailed In-County Paid Subscriptions Stated on PS Form } 3541 \text { (Include paid } \\
\text { distribution above nominal rate, advertiser's proof copies, and exchange copies) }\end{array}$ & 0 & 0 \\
\hline & (3) & $\begin{array}{l}\text { Paid Distribution Outside the Mails Including Sales Through Dealers and Carriers, } \\
\text { Street Vendors, Counter Sales, and Other Paid Distribution Outside USPS }\end{array}$ & 182 & 177 \\
\hline & (4) & $\begin{array}{l}\text { Paid Distribution by Other Classes of Mail Through the USPS } \\
\left.\text { (e.g., First-Class Mail }{ }^{\otimes}\right)\end{array}$ & 0 & 0 \\
\hline \multicolumn{3}{|c|}{ c. Total Paid Distribution [Sum of $15 b(1),(2),(3)$, and (4)] } & 448 & 451 \\
\hline \multirow{4}{*}{$\begin{array}{l}\text { d. Free or } \\
\text { Nominal } \\
\text { Rate } \\
\text { Distribution } \\
\text { (By Mail } \\
\text { and } \\
\text { Outside } \\
\text { the Mail) }\end{array}$} & (1) & Free or Nominal Rate Outside-County Copies included on PS Form 3541 & 0 & 0 \\
\hline & $(2)$ & Free or Nominal Rate In-County Copies Included on PS Form 3541 & 0 & 0 \\
\hline & $(3)$ & $\begin{array}{l}\text { Free or Nominal Rate Copies Mailed at Other Classes Through the USPS } \\
\text { (e.g., First-Class Mail) }\end{array}$ & 0 & 0 \\
\hline & (4) & Free or Nominal Rate Distribution Outside the Mail (Carriers or other means) & 12 & 12 \\
\hline \multicolumn{3}{|c|}{ e. Total Free or Nominal Rate Distribution (Sum of 15d (1), (2), (3) and (4)) } & 12 & 12 \\
\hline \multicolumn{3}{|c|}{ f. Total Distribution (Sum of $15 \mathrm{c}$ and 15e) } & 460 & 463 \\
\hline \multicolumn{3}{|c|}{ g. Copies not Distributed (See Instructions to Publishers \#4 (page \#3)) } & 139 & 47 \\
\hline \multicolumn{3}{|c|}{ h. Total (Sum of $15 f$ and $g$ ) } & 599 & 510 \\
\hline \multicolumn{3}{|c|}{$\begin{array}{l}\text { Percent Paid } \\
(15 c \text { divided by } 15 f \text { times } 100)\end{array}$} & $97.39 \%$ & $97.41 \%$ \\
\hline
\end{tabular}

* If you are claiming electronic copies, go to line 16 on page 3. If you are not claiming electronic copies, skip to line 17 on page 3. 
a. Paid Electronic Copies Nearest to Filing Date

b. Total Paid Print Copies (Line 15c) + Paid Electronic Copies (Line 16a)

0

c. Total Print Distribution (Line 15f) + Paid Electronic Copies (Line 16a)

d. Percent Paid (Both Print \& Electronic Copies) (16b divided by $16 \mathrm{c} \times 100$ )

\begin{tabular}{l|c}
\hline 0 & 0 \\
\hline 448 & 451 \\
\hline 60 & 463 \\
\hline $39 \%$ & $97.41 \%$
\end{tabular}

Q I certify that $50 \%$ of all my distributed copies (electronic and print) are paid above a nominal price.

17. Publication of Statement of Ownership

QIf the publication is a general publication, publication of this statement is required. Will be printed in the 100 issue of this publication.

18. Signature and Title of Editor, Publisher, Business Manager, or Owner
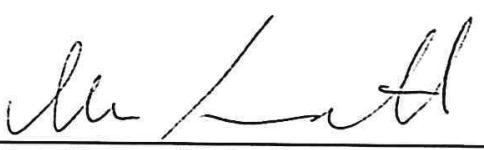

$10 / 01 / 2017$

I certify that all information furnished on this form is true and complete. I understand that anyone who furnishes false or misleading information on this form or who omits material or information requested on the form may be subject to criminal sanctions (including fines and imprisonment) and/or civil sanctions (including civil penalties). 


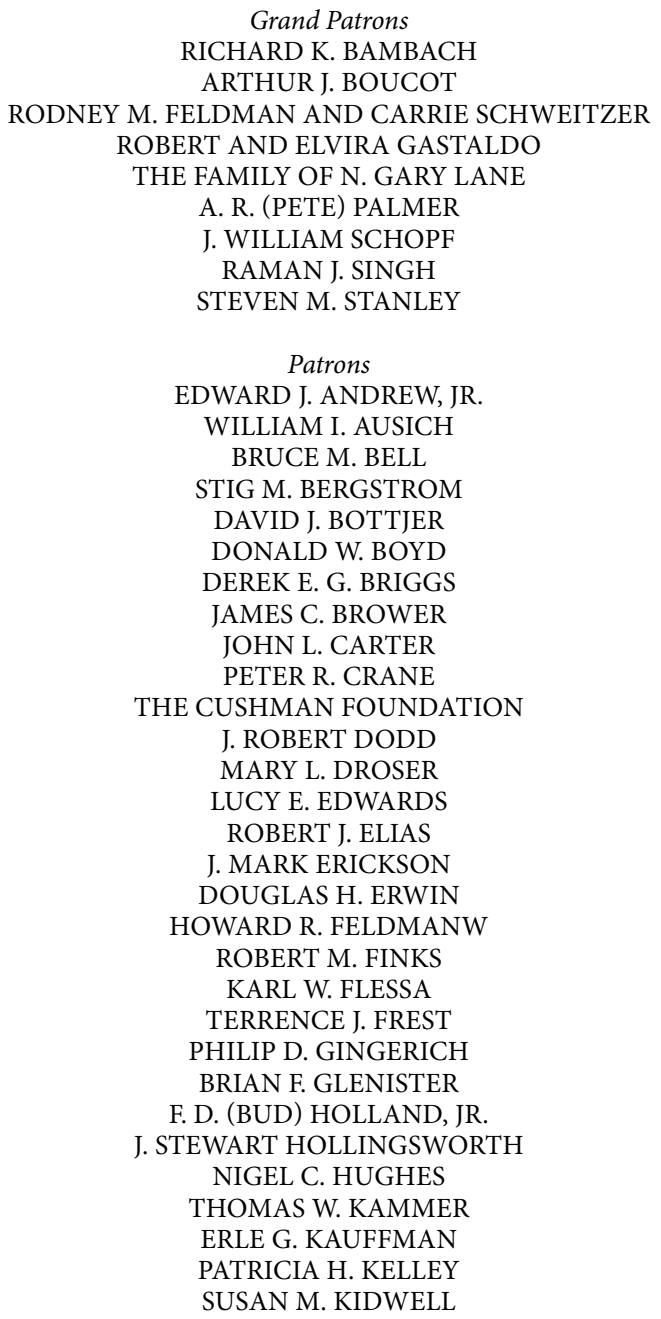

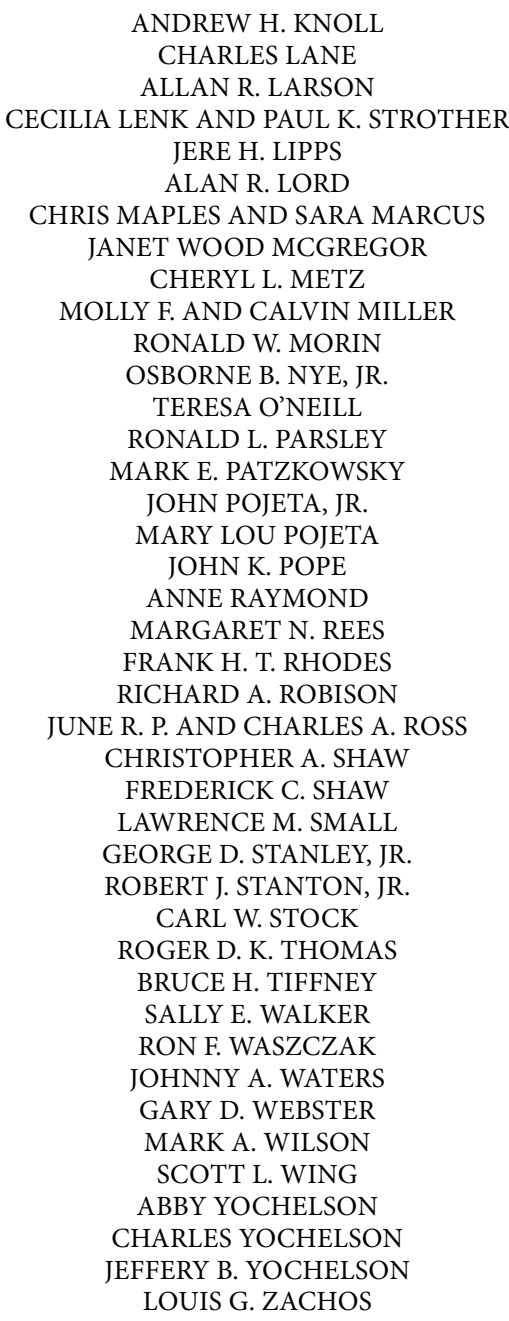

The Journal of Paleontology publishes manuscripts on all aspects of paleontology, including systematics, phylogeny, paleoecology, paleobiogeography, biostratigraphy, taphonomy, and evolution. It emphasizes specimen-based research and features illustrations of the highest quality possible. Manuscript treating all fossil organism groups are welcome, including invertebrates, vertebrates, plants, algae, and microorganisms of all sorts, as well as ichnofossils (trace fossils).

The Journal of Paleontology accepts only online manuscript submissions through the website:

https://mc.manuscriptcentral.com/paleo

Author guidelines can be downloaded at:

https://www.cambridge.org/core/journals/journal-of-paleontology/information/instructions-contributors

For questions regarding online submissions, please contact the editorial offices at:

journalofpaleontology@cambridge.org

Membership Information

Members of the Paleontological Society automatically receive electronic subscriptions to Paleobiology and the Journal of Paleontology as a benefit of membership. To apply for individual membership, please go to the Paleontological Society's homepage at http://paleosoc.org/ where links to an electronic application, a printable paper application form, and a complete list of membership benefits are provided under the Membership heading. 


\title{
JOURNAL of PALEONTOLOGY
}

\author{
VOL 92 | NO 1 | 2018 \\ Cambrian Explosion \\ Zhifei Zhang and Glenn Brock, Guest Editors
}

$1 \quad$ Zhifei Zhang and Glenn A. Brock

New evolutionary and ecological advances in deciphering the Cambrian explosion of animal life

3 Jian Han, Guoxiang Li, Xing Wang, Xiaoguang Yang, Junfeng Guo, Osamu Sasaki, and Tsuyoshi Komiya

Olivooides-like tube aperture in early Cambrian carinachitids (Medusozoa, Cnidaria)

14 Huaqiao Zhang, Andreas Maas, and Dieter Waloszek

New material of scalidophoran worms in Orsten-type preservation from the Cambrian Fortunian Stage of South China

26 Shixue Hu, Bernd-D. Erdtmann, Michael Steiner, Yuandong Zhang, Fangchen Zhao, Zhiliang Zhang, and Jian Han

Malongitubus: a possible pterobranch hemichordate from the early Cambrian of South China

33 Lars E. Holmer, Zhifei Zhang, Timothy P. Topper, Leonid Popov, and Thomas M. Claybourn The attachment strategies of Cambrian kutorginate brachiopods: the curious case of two pedicle openings and their phylogenetic significance

40 Han Zeng, Fangchen Zhao, Zongjun Yin, and Maoyan Zhu

A new radiodontan oral cone with a unique combination of anatomical features from the early

Cambrian Guanshan Lagerstätte, eastern Yunnan, South China

49 Yuning Yang, Xingliang Zhang, Yuanlong Zhao, Yiru Qi, and Linhao Cui

New paleoscolecid worms from the early Cambrian north margin of the Yangtze Platform,

South China

59 Bing Pan, Timothy P. Topper, Christian B. Skovsted, Lanyun Miao, and Guoxiang Li Occurrence of Microdictyon from the lower Cambrian Xinji Formation along the southern margin of the North China Platform

71 Christian B. Skovsted and Timothy P. Topper

Mobergellans from the early Cambrian of Greenland and Labrador: new morphological details and implications for the functional morphology of mobergellans

80 Natalie I. Schroeder, John R. Paterson, and Glenn A. Brock

Eldonioids with associated trace fossils from the lower Cambrian Emu Bay Shale

Konservat-Lagerstätte of South Australia

87 Yunhuan Liu, Qi Wang, Tiequan Shao, Huaqiao Zhang, Jiachen Qin, Li Chen, Yongchun Liang, Cheng Chen, Jiaqi Xue, and Xiaowen Liu

New material of three-dimensionally phosphatized and microscopic cycloneuralians from the Cambrian Paibian Stage of South China

99 Stephen Pates, Allison C. Daley, and Bruce S. Lieberman

Hurdiid radiodontans from the middle Cambrian (Series 3) of Utah

114 Retraction

\section{Cambridge Core}

For further information about this journal please

go to the journal website at:

cambridge.org/jpa 